\title{
Знаки войны и беды в наследии и современной церковной архитектуре Беларуси
}

\author{
И.Н.Слюнькова, НИИ РАХ, Москва
}

Статья посвящена 75-летию победы народа в Великой 0течественной войне. Масштабы разрушений Беларуси в годы войны не поддаются методам исчисления, они невосполнимы, и для республики, как показывает время, традиционный опыт реставрации не является универсальным решением проблемы возвращения ценностей исторического прошлого. В статье внимание сосредоточено на исследовании особого пути Беларуси в деле возрождения храмов.

Судьба наследия церковной архитектуры республики рассматривается, начиная с военных утрат и последующего забвения сакральных объектов, до времени возрождения храмов. Поднимается тема обращения к понятию «знак беды», вопросы состояния церковной архитектуры Беларуси на рубеже XX-XXI веков. Отмечены тенденции современного искусства к превращению трагических смыслов истории в синонимы преодоления и национального возрождения.

Представлены главные приметы нашего времени, связанные с воссозданием и реставрацией ценных объектов наследия. Воссоздание Успенского собора в Витебске послужило цели возрождения архитектурной доминанты древнего города. Собор был построен монахами ордена базилианов при участии итальянских мастеров (1743-1777) и уничтожен в годы атеизма (1936). Передача верующим и реставрация Николаевского гарнизонного собора в Брестской крепости позволила вернуть в культуру выдающийся памятник архитектуры византийского стиля эпохи историзма. Храм был построен по проекту академика Д.И. Гримма (1874-1877), и летом 1941 года в огне обороны Брестской крепости от фашистов он был разрушен. Показано, как решалась проблема компенсации утраченных в войну церковных зданий путём устройства временных церквей на территории Беларуси в начале XXI века.

Поднимаются вопросы поисков современной типологии архитектуры православного храма. Особое внимание отводится строящейся в Минске церкви во имя Всех Святых по всему миру просиявших. Затрагиваются вопросы семантики архитектуры военного мемориала в стенах храма-памятника.

Ключевые слова: Беларусь, храм, история, церковная архитектура, война, беда, памятник, культурное наследие, воссоздание, реставрация, сакральное, символика, национальное.

Signs of War and Disaster in the Heritage and Modern Church Architecture of Belarus

I.N. Slyunkova, NII RAH, Moscow
The article is dedicated to the 75th anniversary of the victory of the people in the Great Patriotic War. The scale of destruction of Belarus during the war years cannot be calculated, it is irreplaceable, and for the Republic, as time has shown, the traditional experience of restoration is not a universal solution to the problem of returning the values of the historical past. The article focuses on the research of a special way of Belarus in the revival of temples.

The fate of the heritage of the church architecture of the Republic is considered, starting from the military losses and the subsequent oblivion of sacred objects, up to the time of the revival of temples. The theme of addressing the concept of "sign of distress", the issues of the state of church architecture in Belarus at the turn of XX-XXI centuries are raised. The tendencies of modern art to transform the tragic meanings of history into synonyms of overcoming and national revival are noted.

The article presents the main signs of our time related to the reconstruction and restoration of valuable heritage objects. Restoration of the Assumption Cathedral in Vitebsk served the purpose of revival of the architectural dominance of the ancient city. The cathedral was built by monks of the Basilian order with the participation of Italian craftsmen (1743-1777) and destroyed during the atheism years (1936). Transfer to the believers and restoration of St. Nicholas Garrison Cathedral in the Brest Fortress allowed returning to culture the outstanding monument of architecture of the Byzantine style of the era of historicism. The temple was built according to the project of academician D.I. Grimm (1874-1877), and in summer 1941 it was destroyed in the fire of Brest Fortress defense against fascists. It shows how the problem of compensation for the church buildings lost during the war was solved by building temporary churches in Belarus at the beginning of the XXI century.

Questions of search of the modern typology of the architecture of an orthodox temple are raised. Special attention is paid to the church under construction in Minsk in the name of All Saints Who Shone All Over the World. The issues of the semantics of the architecture of the military memorial within the walls of the monument temple are also touched upon.

Keywords: Belarus, temple, history, church architecture, war, disaster, monument, cultural heritage, recreation, restoration, sacred, symbolism, national.

Тема сохранения и восстановления памятников культового зодчества, пострадавших, разрушенных, погибших в годы Великой Отечественной войны, чаше всего рассматривается в 
русле развития науки и практики архитектурной реставрации. Спасение памятников, даже малая толика вклада каждого, становится сродни участию в деле великого подвижничества. Сохранение и грамотное использование, реставрация объектов церковного искусства, как и сама жизнь, процесс непрерывный. Постепенное приращение храмов за счёт забытого наследия в последнее время заметно ускоряется и развивается по экспоненте.

Между тем для Беларуси обращение к историко-культурным ценностям, сакральному назначению храмовой архитектуры невозможно раскрыть, исходя из одного лишь опыта

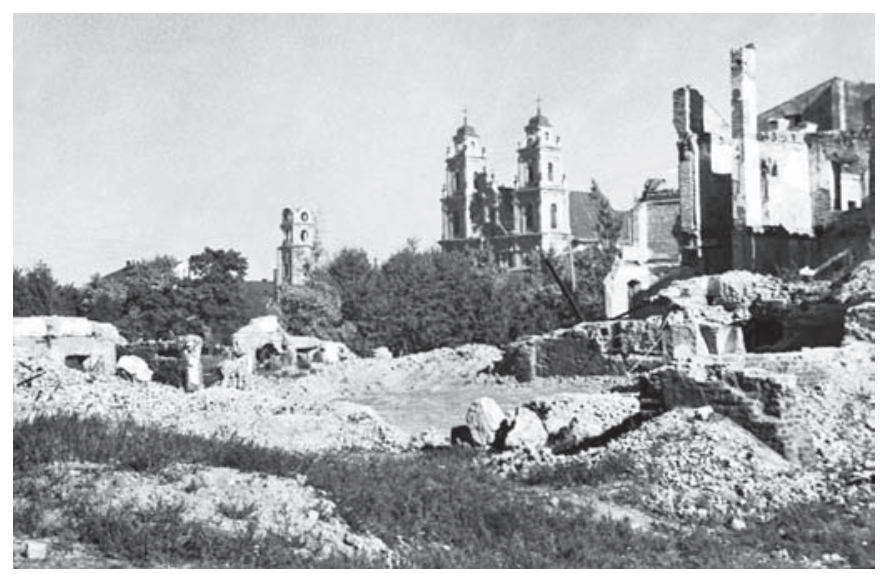

Рис. 1. Минск. Соборная площадь. Фото 1943 года

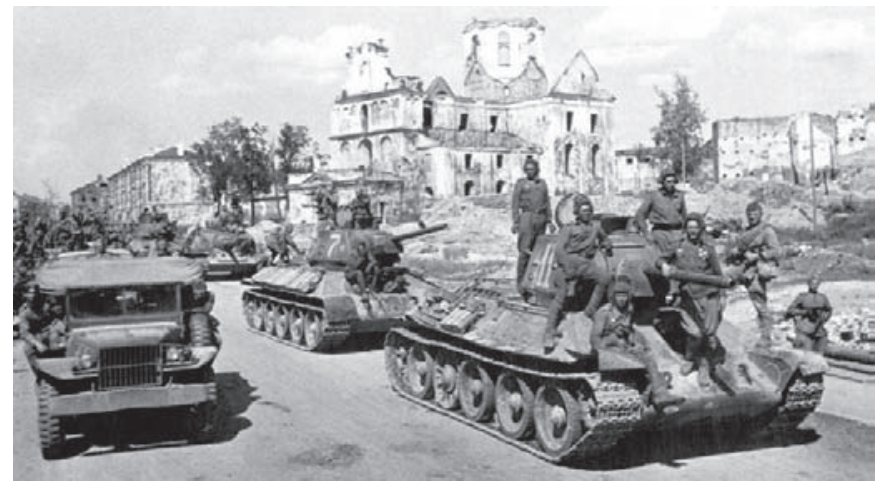

Puс. 2. Могилёв. Богоявленский монастырь XVII. Фото 1943 года

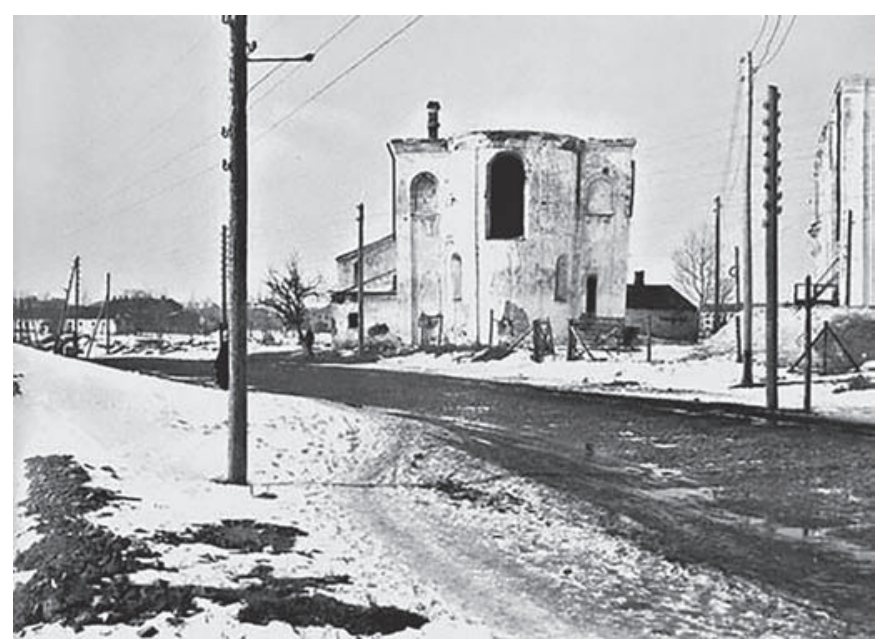

Рис. З. Витебск. Богоявленская церковь ХІІ века. Фото 1943 года реставрационных мероприятий. Картина поступательного возвращения ценностей здесь в меньшей степени отвечает действительности.

Основными импульсами возрождения храмов Беларуси, как насущной проблемы общества, становились чрезвычайные обстоятельства - военные катаклизмы, реакция на них и другие критические моменты истории. Возрождение храмов приходилось на время, когда в действительности стоял вопрос библейского масштаба, - о спасении или гибели народа.

Разрушения, постигшие республику во время Великой 0течественной войны, были тотальными и нанесли чудовищный урон. Жесточайшие утраты белорусские земли ощутили на себе дважды. Вначале враг, преодолевая сопротивление и сметая все на своём пути, наступал на Москву, а после перелома в войне армия-победительница гнала захватчиков обратно, и Беларусь снова становилась полем битвы. (Так было в каждую из войн - Северную со шведами, Отечественную с Наполеоном и др.).

Насколько сильно были разрушены города, показывает военная хроника 1943 года. В пепел превращена Соборная (Советская) площадь Минска, уцелел один единственный иезуитский костёл. В руинах древний Могилёв, разбиты великолепный Братский Богоявленский собор и монастырь со знаменитой типографией XVII века. Тотально разрушен Витебск, где среди выжженной земли обломки остова Благовещенской церкви XII века [1] (рис. 1, 2, 3).

После войны вопросы сохранения памятников уступали место физическому спасению жизни. Многие церковные сооружения так и оставались годами в руинах, другие, подлежащие ремонту, спешно восстанавливали в целях хозяйственной деятельности. Как и в России, они превращались в архивы, кинотеатры, склады, другие места общественного назначения. Приспособление кардинально изменяло исторический облик храмов, оставляя их без реставрации в искажённом виде.

Забота о памятниках архитектуры оставалась уделом немногих специалистов - историков и архитекторов. В архиве сохранились документы проведённых М.С. Кацером обследований храмов XVIII века в Чечерске, связанных с проектом знаменитого Д. Кваренги и разрушенных в войну [2].

Письмо по охране памятников в адрес руководства Компартии Белоруссии направил академик архитектуры Н.Я.Колли, директор Института истории и теории архитектуры Академии архитектуры СССР. В нём говорилось о четырёх наиболее древних объектах наследия: Софийском соборе и Спасской церкви Евфросиниевского монастыря в Полоцке, Коложской церкви в Гродно и Благовещенской в Витебске ${ }^{1}$.

В 1960-е годы основной движущей силой сохранения и использования наследия выступала наука. По известным причинам интересы её склонялись в пользу изучения граждан-

${ }^{1}$ Письмо директора Института истории и теории архитектуры Академии архитектуры СССР академика Н.Я. Колли секретарю ЦК КП(б)Б Т.С. Горбунову (Москва, 9 января 1945) // Беларусь сегодня. - Режим доступа: https://www. sb.by/articles/do-polnoy-pobedy-eshche-tri-mesyatsa.html 
ской архитектуры и истории градостроительства. Культовое зодчество республики предъявлялось обществу в то время ограниченным кругом памятников. На первый план выходили оборонного типа церкви рубежа XVI-XVII веков: Сынковичи, Мурованка (Мало-Можейково), Камаи. Они служили образцами неповторимого своеобразия белорусского зодчества. В науку эти памятники были введены до революции трудами Императорской археологической комиссии.

Ничего не говорилось в советское время о сосуществовании в истории Беларуси, начиная с XIV века, двух основных христианских конфессий и о проблеме поляризации и отражения в архитектуре православной и католической церковной традиций. Притом разно-конфессиональное присутствие во многом и являлось чертой историко-культурной идентичности белорусских земель, фактором отличия их архитектуры от архитектуры соседней России.

Сложилось правило изучать церковную архитектуру снаружи, показывая только объёмно-пространственную композицию и внешний вид храма. Реставрация была направлена на восстановление исторического внешнего облика сооружений в системе застройки города. Соответственно, публиковались планы, фасады, в редких случаях разрезы церковных сооружений. Объекты церковного наследия предъявлялись обществу в усечённом виде. Из музейного показа изымалось первостепенное по сакральному содержанию и художественной значимости внутреннее церковное пространство.

Единичные действующие в Беларуси храмы, переданные Русской православной церкви, включая Жировичский монастырь с расположенной в его стенах духовной семинарией, по большей части оставались малоизученными. Построенные или перестроенные в XIX веке они считались поздними, детищем эпохи капитализма и по состоянию науки 1960-1980-х годов квалифицировались как объекты, не представляющие исторической и культурной ценности.

Казалось, что из памятников церковной архитектуры на белорусской земле сохранились единицы зданий, а остальные как будто уничтожены жерновами чудовищной войны, послевоенной разрухи. Действительное положение вещей с недвижимыми памятниками оставалось фактически не проявленным. Несколько ирреальная картина провалов в небытие целых пластов наследия выделяла Беларусь на фоне России, Украины, Литвы, других республик.

Перемены наметились на рубеже 1970-1980-х годов. Произошло важное и даже переломное событие, не получившее однако должного общественного резонанса. Был создан 7-томный труд Свода памятников истории и культуры Беларуси, который готовился в составе инициированного государством всесоюзного проекта. Натурные исследования и экспедиции по выявлению и фиксации сооружений исторического прошлого, объективный анализ полученных данных показали неожиданный результат.

0бнаружилось, что основная доля недвижимых памятников историко-культурного наследия Беларуси однозначно относится к церковной архитектуре. Храмы уцелели и, словно под спудом, продолжали существовать, но только в разной степени сохранности, неявно, как будто ожидая своего часа. Составители Свода сделали открытие о наличии на белорусских землях огромного числа неучтённых ранее исторических церковных зданий.

Память недавней войны оставалась альфой и омегой Беларуси. В связи с публикацией Свода возникала проблема приведения объективных данных экспедиций и новых открытий в соответствие со сложившейся парадигмой общества. Решение проблемы сводилось к идее поместить в одном ряду с памятниками довоенной архитектуры все мемориальные знаки Великой Отечественной войны.

Вторым открытием Свода было то, что число военных мемориалов в Беларуси настолько огромно, что с трудом поддаётся осознанию. Почти на каждом развороте книг Свода памятников Беларуси стоят скорбные обелиски, стелы и скульптурные композиции, которыми отмечены массовые захоронения и братские кладбища, могилы советских солдат и партизан. Церковную архитектуру уровняли с, по-белорусски, «могілкамі» жертв войны и героев Великой Победы [3]. Отметим, что ни в одном из Сводов памятников других республик ничего подобного не было (рис. 4). Тогда же, почти что нарицательным становилось в республике понятие «знак беды», которое активно разраба-

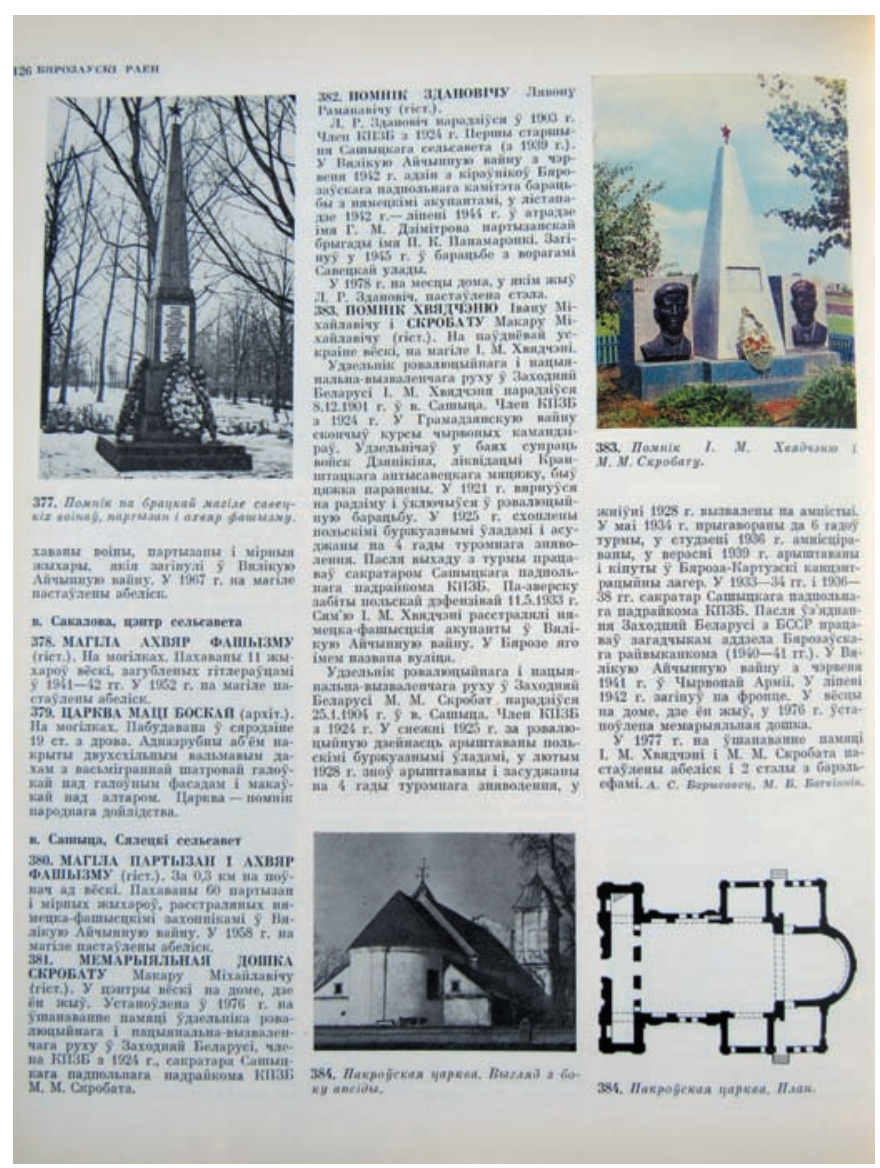

Рис. 4. Свод памятников истории и культуры Белоруси. Брестская область [3]. Фрагмент 
тывалось в художественной литературе. Эта формула широко известна по названию фильма, снятого по повести В. Быкова.

Распад страны 25 декабря 1991 года стал новым критическим моментом истории. В независимой Республике Беларусь, как и в других республиках бывшего СССР, на первое место ставились вопросы государственного строительства, самостоятельной экономики, национальной идентичности. В народе же в условиях слома эпох и поставленных перед каждым вопросов выживания, на уровне личностного сознания главным становились поиски опоры в вере.

Приметой 1990-2010-х годов было восстановление и реставрация объектов церковного наследия. Явление это по-настоящему не изучено и, надо думать, такой пробел в науке со временем будет устранён. На первое место выходило воссоздание главных храмовых святынь, утраченных в войне и в годы атеизма.

В республике воссозданы погибшие во время войны соборные храмы Святого Духа XVII века в Минске, Рождества Богородицы XVIII века в Орше. Огромное значение имело воссоздание Успенского собора в Витебске, разрушенного в 1936 году. История его восходит к древности и отмечена многими поворотами событий. Вначале на одной из наиболее высоких отметок, на берегу Западной Двины возвели православную Пречистенскую церковь. B XVII веке она пере-

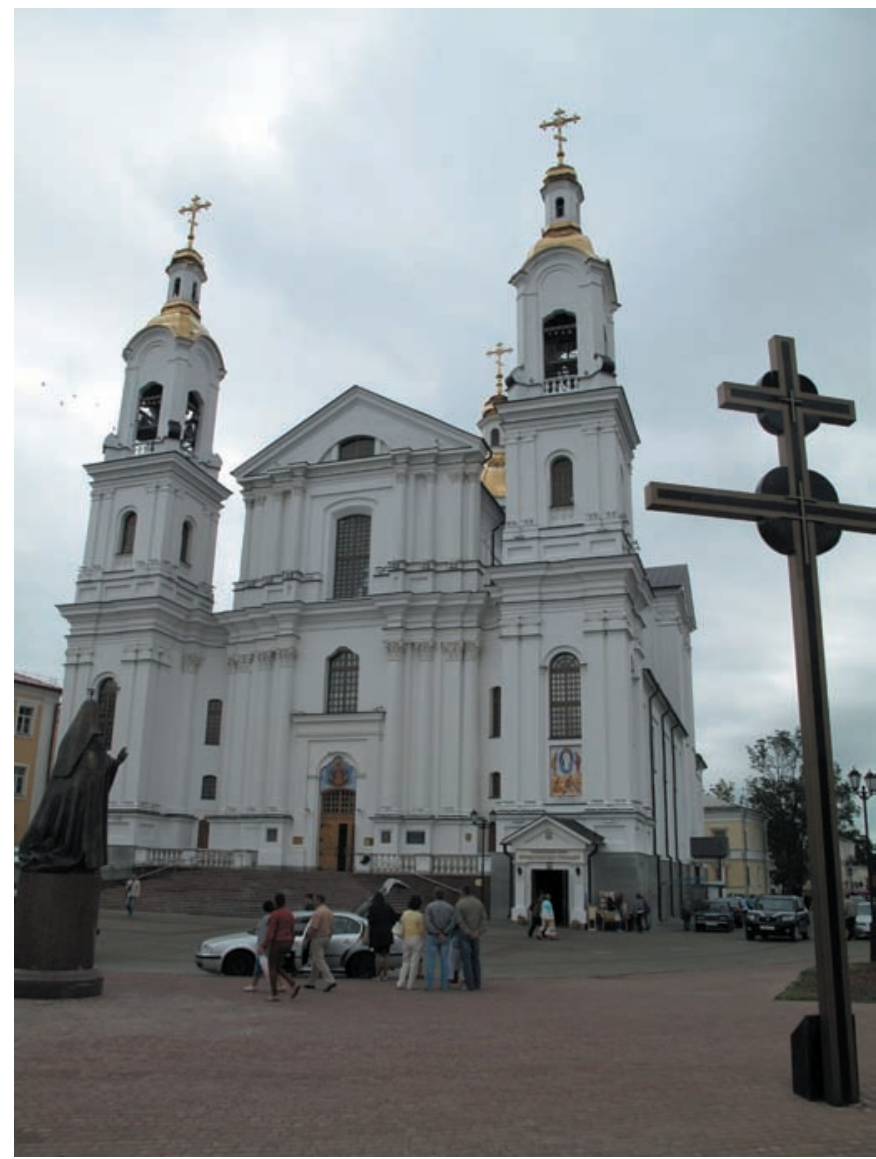

Рис. 5. Витебск. Успенский собор. Фото И.Н. Слюньковой. 2014 200 дана униатам, и в 1743-1777 годы на месте старого здания построено новое монументальное сооружение, в 1799 году ставшее кафедральным собором. Каменный Успенский собор построили в формах двухбашенной купольной базилики, для фундамента на слабых грунтах специально разработали и заложили мощные инженерные конструкции на деревянных сваях и провели укрепление берега реки.

Работы по воссозданию Успенского собора осуществлялись с 1998 до 2011 года (рис. 5). Решалась задача восстановления главной и самой эффектной архитектурной доминанты, определявшей узнаваемый силуэт древнего города. С воссозданием собора Витебску вернули его сакральное значение, историческую идентичность. Проблема устойчивости здания была решена путём устройства мощного стилобата, позволившего устроить подземную церковь во имя Преображения Господня, которой раньше не было. Над её поминальным столиком таблица с молитвой «Все святые молят Бога о нас» (рис. 6).

Возобновление богослужения, реставрация первоначальных форм храмов связаны с предварительными исследованиями и ценными находками по истории, культуре, искусству. Настоящим открытием последних десятилетий является Николаевский гарнизонный собор Брестской крепости. В Своде памятников Беларуси статья о нём отсутствует, и публикации

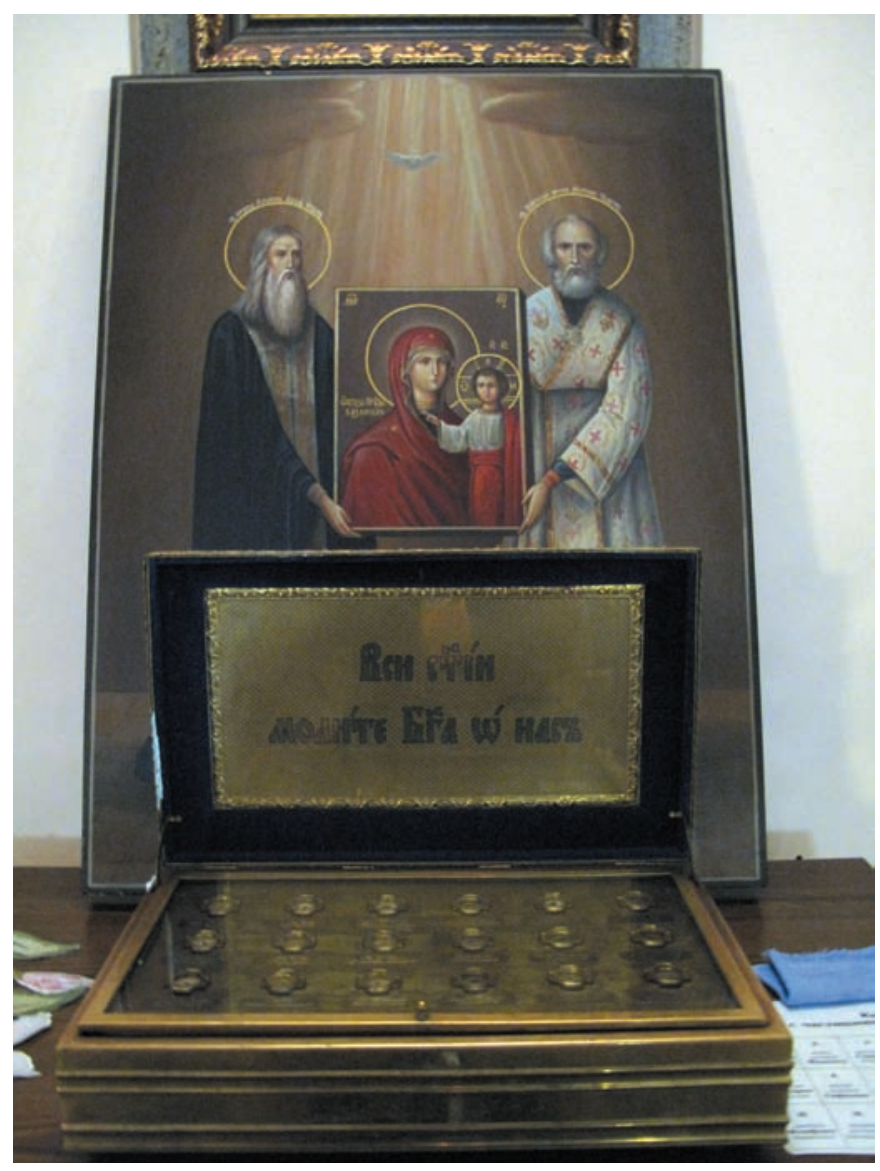

Рис. 6. Витебск. Молитва на помнальном столике подземного храма. Фото И.Н. Слюньковой. 2014 год 
стали появляться только после возвращения храма священству, прихожанам в 1991-1994 годы [4]. Зданию вернули функции храма, после чего появилась возможность войти в него и по-настоящему оценить красоту и выразительность архитектуры сакрального пространства, гармонию, лаконичность и изысканность форм и деталей.

Собор построен в 1874-1876 годах, освящён в 1877 году. Относится к первым произведениям византийского стиля эпохи историзма и имеет существенное значение для истории архитектуры Беларуси и России. Возводился по проекту петербургского архитектора академика Д.И. Гримма, под руководством военного инженера капитана А.М. Иванова. По заказу Александра II храмы византийского стиля строились (одновременно с брестским) в то время в Херсонесе, Тифлисе, Копенгагене, Женеве, Вифлееме. Для каждого из них Д.И. Гримму предстояло отыскать свои неповторимые решения.

Стереометрия объёма и высота собора в Брестской крепости были регламентированы требованиями военной архитектуры. С учётом местоположения храма, который размещён посредине цитадели и внутри кольца укреплений, в основу композиции положена прямоугольная в плане купольная базилика с характерным горизонтальным силуэтом. Доминантой композиции является поставленный над средокрестием большой пологий световой купол. Благодаря такому решению и пропорциям сооружения достигаются пространственные и световые эффекты, отсылающие к прообразу и главной византийской святыне - Св. Софии в Константинополе.

Дальнейшая история храма связана с войной. Во время Первой мировой войны Россия в 1915 году уступила крепость германским войскам, а в 1918 году город был передан Польше. В 1920 он отвоёван Красной армией, а в 1921 году снова отошёл к Польше. В 1922-1930 годы собор перестроен в костёл.

В 1939 году Брест занимают фашистские войска, а далее, по договору Молотова-Риббентропа он становится частью СССР. После внезапного нападения фашистской Германии Брестская крепость держала героическую оборону с 22 июня по 20 июля 1941 года. Для защитников крепости храм стал одним из главных пунктом обороны. Он сильно пострадал, но

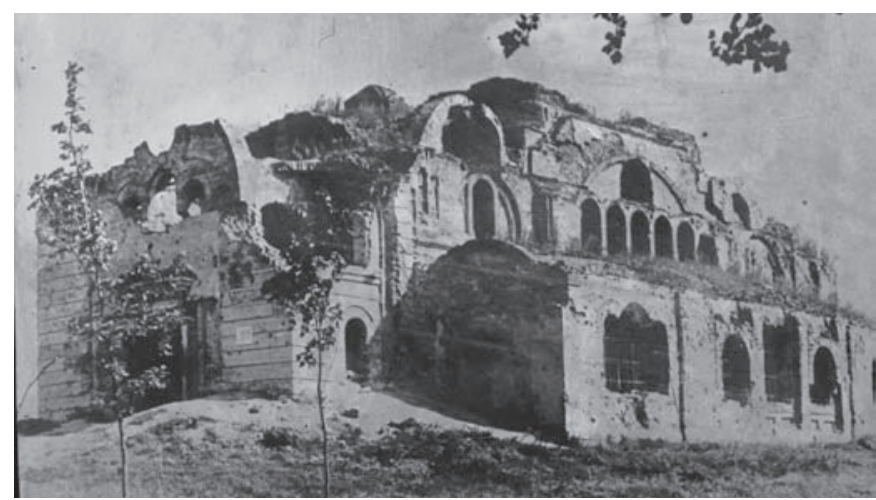

Рис. 7. Брестская крепость. Николаевский гарнизонный собор. Фото 1965 года основные несущие конструкции выдержали. В 1965-1972 годы собор включён в состав мемориального комплекса «Брестская крепость-герой», его фасады и своды были восстановлены и отреставрированы (рис. 7, 8,9).

Иная ситуация сложилась в Могилёве, где в годы войны было уничтожено подавляющее число храмов. В начале 2000-х годов для районов новой застройки экстренно потребовалось устройство временных церквей. Проблема снималась благодаря использованию железнодорожных вагонов. Они приспосабливались для богослужения, на что извне указывала поставленная над крышей церковная глава с крестом. Удивительный по силе воздействия образ церкви, которая нуждается в собственном доме и одновременно церкви торжествующей, сильной духом, по прошествии нескольких лет уже остался позади. Свидетельства о том, что это было в реальности, сохранились на фотографиях 2011 года, когда в Могилёве стояли несколько подобных временных церквей (рис. 10).

Строительство новых храмов Беларуси - отдельная тема исследований. С ней связаны проблемы поиска новой типологии церковных сооружений, отвечающей современным реалиям и потребностям общества, с учётом технологических прорывов в области коммуникаций, строительных конструкций, материалов, методов производства. Согласно учению

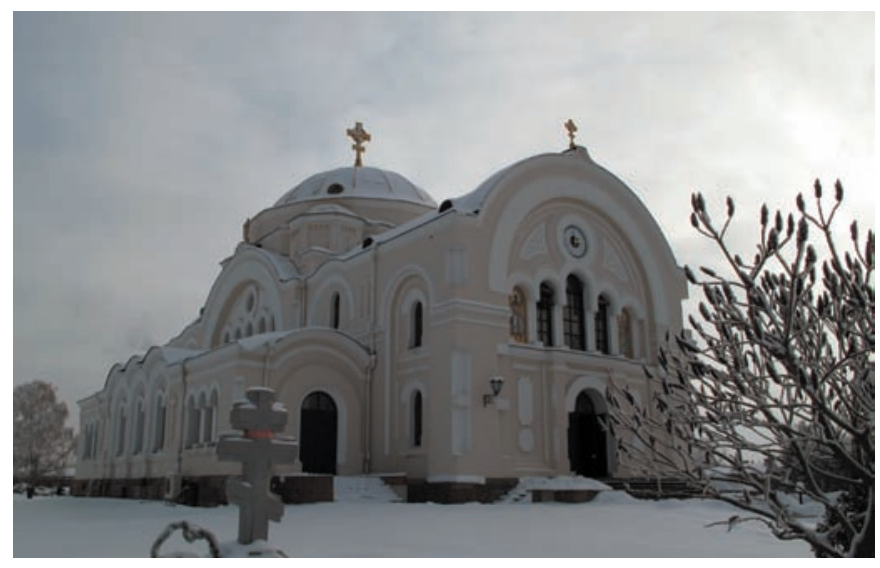

Рис. 8. Николаевский гарнизонный собор. Реставрация. Фото И.Н. Слюньковой. 2010 год

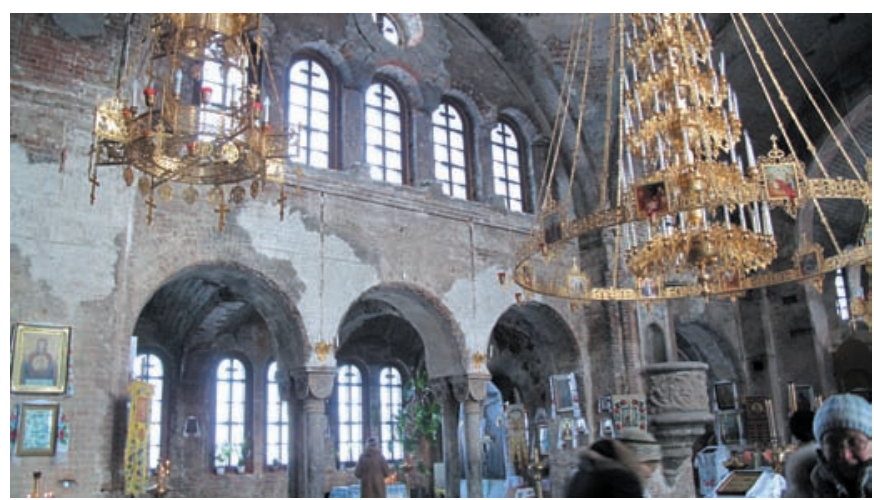

Рис. 9. Николаевский гарнизонный собор. Интерьер. Фото Слюньковой. 2010 год 
церкви, главным остаётся связь с традицией. Но среди прочего приметой нового в храме зачастую становится обращение к истории в ракурсе дня насущного, стремление её понять, переосмыслить согласно новым достоверным данным.

Постараемся отметить некоторые точки соприкосновения между храмовой архитектурой сегодня и нарративом трагедии войны как свойством исторической памяти белорусов. Такая постановка вопроса правомерна в связи со строящимся храмом во имя Всех Святых в Минске.

Это первое в республике крупное сооружение храма-памятника. Оно поставлено не в центре Минска, а на периферии, расположено в районе Зелёный Луг, на обширном участке с отступом от окружающей застройки. Архитектурный замысел сооружения принадлежит протоиерею о. Фёдору (Повному), настоятелю и автору идеи храма, который в одном из интервью, определяя свою позицию, говорит об измерении понятия «личность», о творческом начале в людях: «в культуре сейчас много новых хороших идей, но есть и ужасающие моменты. Никто не отменял законы гармонии, красоты и глубину творческой мысли, предугадывание». Он размышляет об «опыте большой Родины», о том, что, возможно, «дальше нас будет разводить время» [5]. Церковное искусство обращено к личности, частному человеку, и такая позиция ближе всего к идее храма, ведь двери его открыты для каждого. Право-

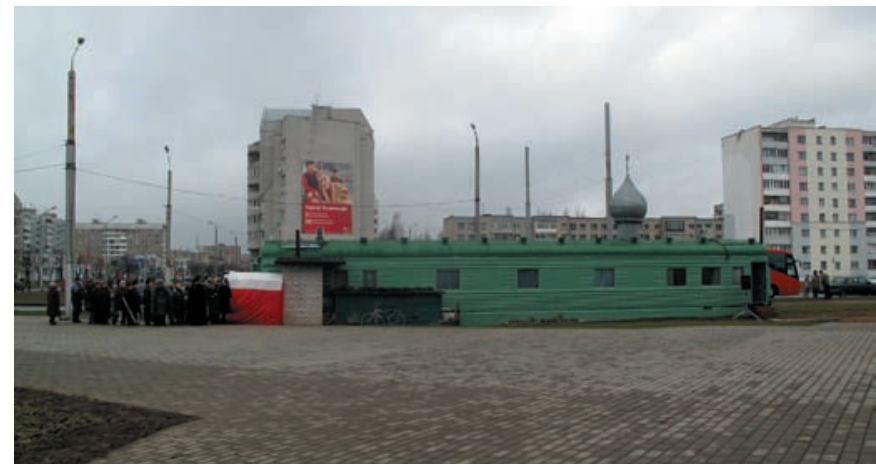

Рис. 10. Могилёв. Временная церковь. Фото И.Н. Слюньковой. 2011200

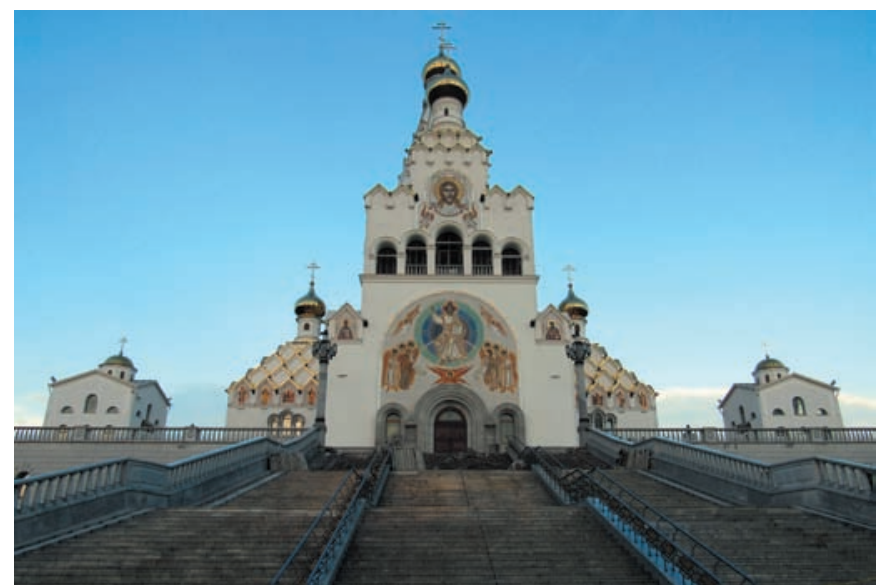

Рис. 11. Минск. Храм-памятник Всех Святых. Главный фасад. Фото И.Н. Слюньковой. 2015 год славное церковное искусство служит выражению частных и вневременных смыслов, эстетизации среды и органичному вхождению, адаптации того, что возвышает человека, в природе, повседневной жизни.

Оставим в стороне вопросы архитектурного образца, анализ композиции церкви в Минске, общие типологические закономерности построения храма-памятника. Остановимся только на особенных и отличительных чертах.

Абсолютно необычным представляется замысел структуры сооружения, направленный на соподчинение храмовых и общественно-значимых светских пространств. Они предназначены для литургического действия и частной молитвы, храмового мемориала и связанных с ним ритуалов памяти, проведения процессий.

Храм-памятник имеет три престола, заключённых в самостоятельные объёмы. Центральный большой шатровый храм освящён во имя Всех Святых по всему миру просиявших. Две придельные церкви освящены во имя иконы Божией Матери Утоли моя Печали (северный верхний) и во имя Усекновения главы Иоанна Предтечи (северный нижний). В объём сооружения включены также комплекс духовного учебного центра, места общественных собраний, концертных площадок и др. При этом все традиционные пространственные формы и функции православного храма соблюдены. Складывается новый тип сакраль-

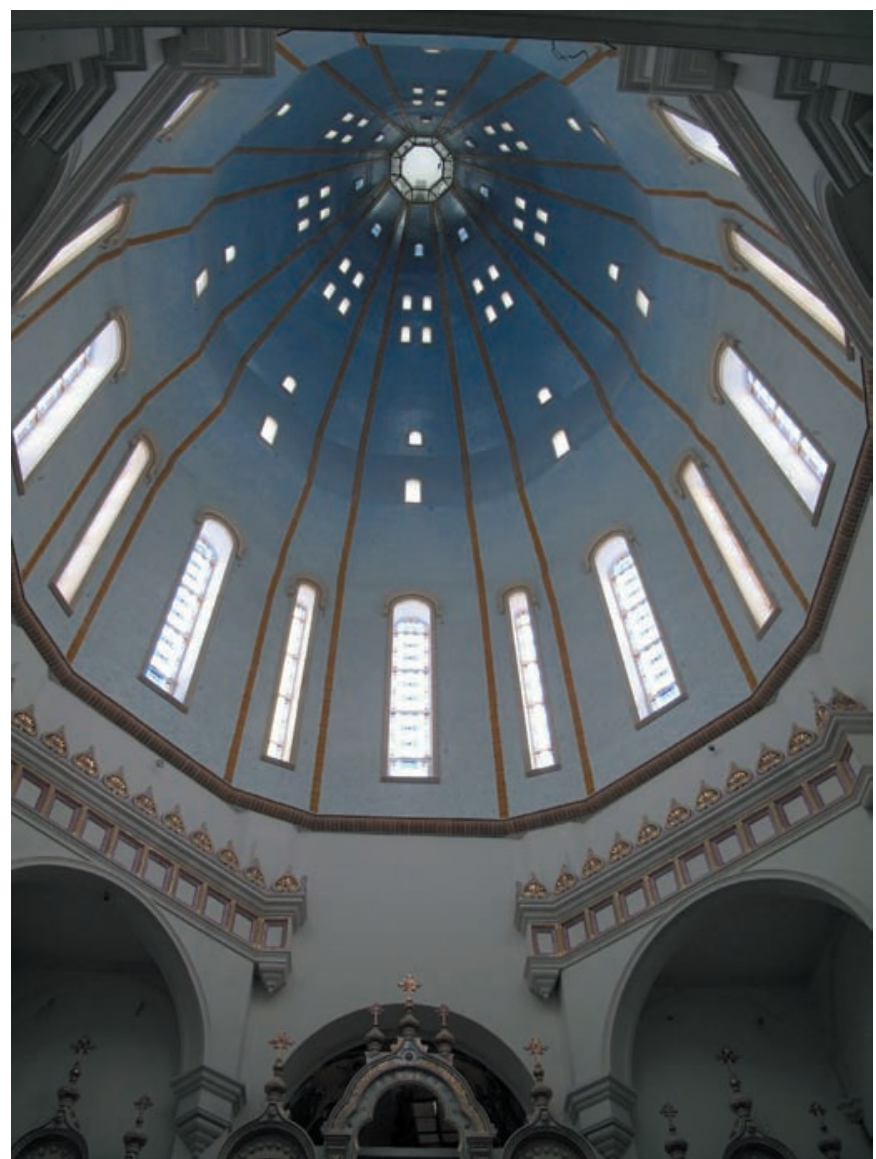

Рис. 12. Храм-памятник Всех Святых. Своды храма центрального престола. Фото И.Н. Слюньковой. 2016 год 
ного сооружения-кластера, в котором соединяются традиция и новое видение предназначения церковного здания (рис. 11, 12).

Особенно ярко и необычно выстроена и реализована в архитектуре многосложная программа и целостная концепция храмового мемориала. Для него в объёме церкви отведены подземные пространства. Отдельный вход в мемориальную зону устроен в восточной стене подклета на уровне земли. Оформление двери входа задаёт символику начала перехода извне в сакральные пространства. Светлый вестибюль украшен мозаичными композициями библейского содержания в иконографии известных памятников белорусского церковного искусства. Посредине помещения световой фонарь-кристалл в форме стеклянной пирамиды. По двум симметричным боковым лестницам, опирающимся на стены, осуществляется спуск вниз, где находится анфилада подземных залов. В центре главного зала, под сенью каменного кивория неугасимая лампада с благодатным огнём из Иерусалима. Восточная стена оформлена в виде пристенного алтаря, очевидно, в напоминание о сосуществовании православной и католической христианскихтрадиций в истории края.

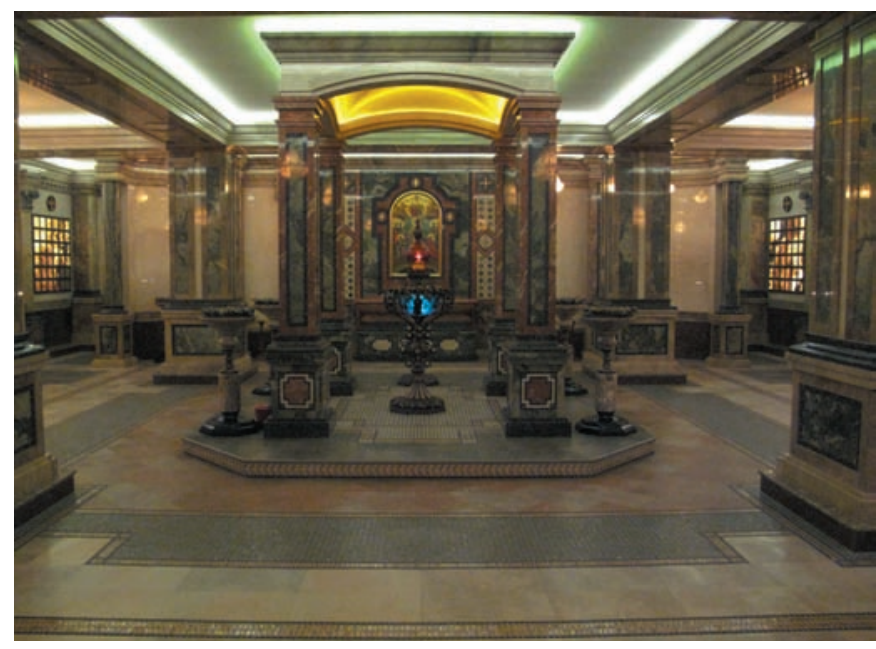

Puc. 13. Храм-памятник Всех Святых. Главный зал мемориала. Фото И.Н. Слюньковой. 2016 год

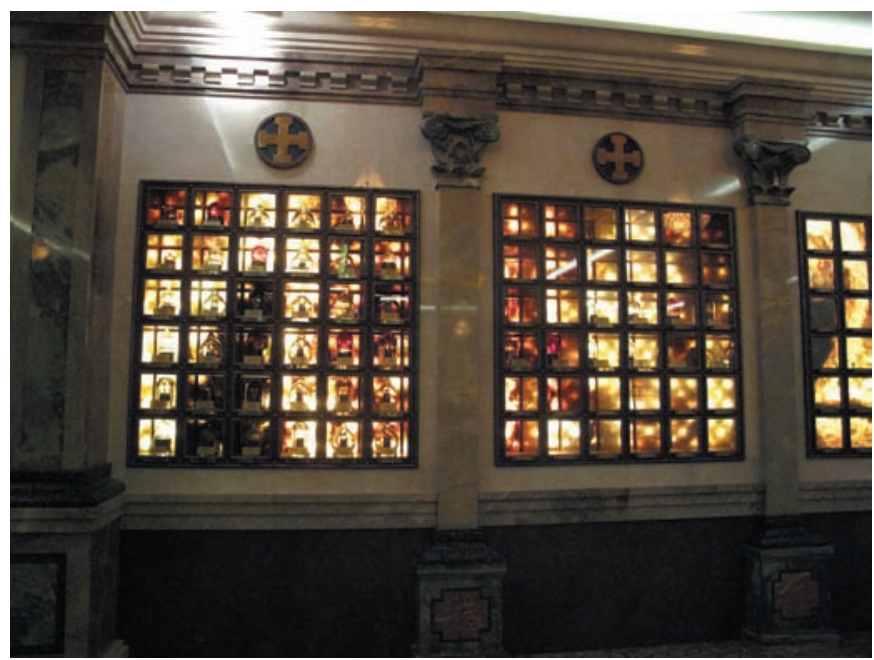

Рис. 14. Храм-памятник Всех Святых. Стена реликвий. Фото И.Н. Слюньковой. 2016 год
На боковых стенах расставлены не повторяющиеся по своим формам стеклянные сосуды, в которых заключены скорбные белорусские реликвии XX века: частицы земли, омытые кровью павших; гильзы погибших воинов-афганцев, которые их матери принесли в храм. Здесь предметный мартиролог Беларуси, священной героической истории, наглядное присутствие топонимов жестоких сражений, сожжённых деревень, лагерей смерти и, разумеется, Хатыни. Напротив центрального помещения расположен зал-камера и в классическом назначении крипта. Здесь в саркофагах

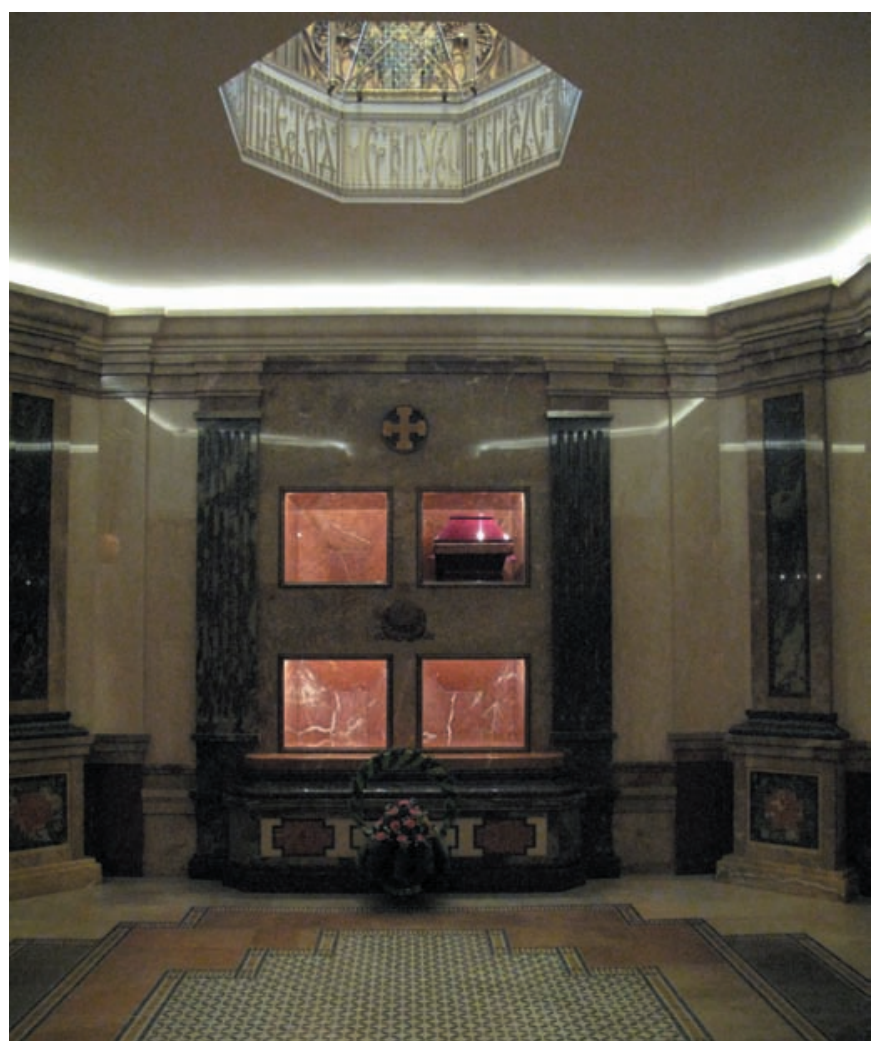

Рис. 15. Храм-памятник Всех Святых. Крипта. Фото И.Н. Слюньковой. 2016 год

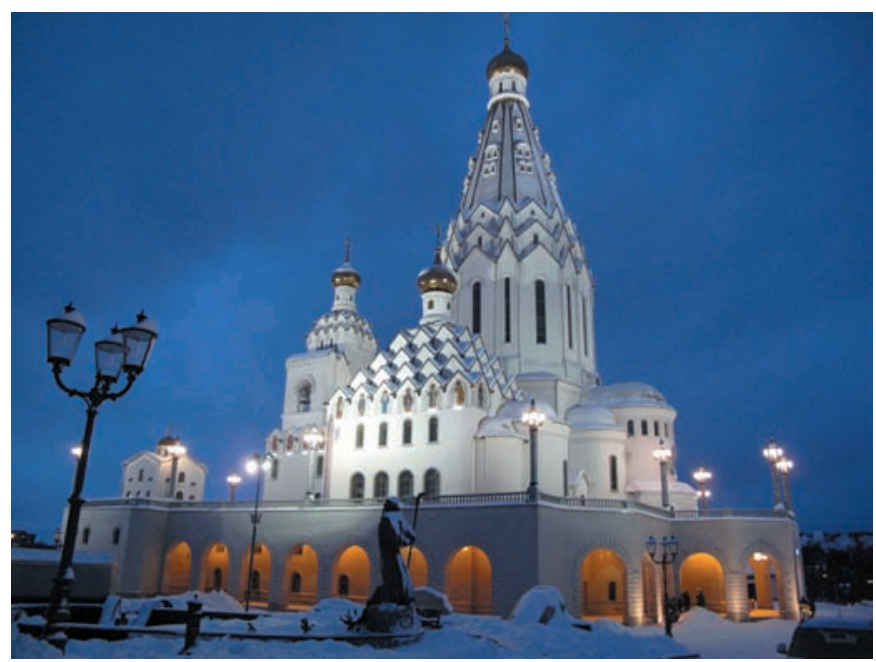

Рис. 16. Храм-памятник Всех Святых. Южный фасад. Фото И.Н. Слюньковой. 2016 год 
покоятся солдат войны 1812 года, солдат Первой мировой, солдат Великой Отечественной (рис. 13, 14, 15, 16).

В итоге, подземный этаж храма, где всё, от анфилады заловкамер до каждого из предметов, наделяется конкретными мемориальными смыслами, подводит к утверждению сакрализации трагической памяти своего национального прошлого. Архитектурно-пространственные формы храма и окружающие его пространства неотделимы от сакрально-ритуального эстетического действа. Ритуально-процессиональная программа архитектуры превращена в один из главных аспектов замысла сооружения.

Системой символов в храме, как кажется, с удвоенной силой проявляется столкновение вещей, на первый взгляд несопоставимых, - катастрофы войны и выморочного статуса сакрального наследия. Возможно, в этом заключается правда жизни, указывавшая на себя при выходе в свет томов Свода памятников Беларуси, и «знак беды» как метка генетической памяти белорусов. Тема национального в современном церковном искусстве утверждается посредством превращения, конверсии трагических смыслов истории в синонимы пути преодоления и возрождения народа, края, республики.

\section{Лuтература}

1. Макарычев, М. Удар «Багратиона» // Мультимедийный интернет-портал «СОЮЗ. Беларусь-Россия». - Режим доступа:https://rg.ru/2019/06/22/75-let-nazad-nachalasoperaciia-po-osvobozhdeniiu-belarusi-ot-fashistov.html (дата обращения 10.03.2020).

2. [Документы по архитектуре Беларуси из личных фондов деятелей культуры. Фонд архива М.С. Кацера. 1948 г.] // Институт искусствоведения, этнографии и фольклора им. К. Крапивы НАН Беларуси. Режим доступа: https://archives.gov. by/index.php?id=707874 (дата обращения 15.03.2020).

3. Збор помнікаў гістрыі и культуры Беларусі. У 7 тамах. - Мінск, 1984-1988.

4. Горбачёв Н. Николаевский гарнизонный собор в Брестской крепости / Н. Горбачев // Мир Божий. - 2012. - № 18. - С. 87-89.

5. Повный Ф., свящ. Храмовое сооружение как проповедь, а храмовое пространство традиционно / Ф. Повный, свящ. // Литературная газета. - 2020. № 4 (6722).
6. [Цикл публикаций материалов из Национального архива Республики Беларусь к 70-летию Великой Победы] // Беларусь сегодня. - Режим доступа: https://www.sb.by/ articles/do-polnoy-pobedy-eshche-tri-mesyatsa.html (дата обращения 20.02.2020).

\section{Reference}

1. Makarychev M. Udar «Bagrationa» [Strike "Bagration"]. Mul'timediinyi internet-portal "SOYuZ. Belarus'-Rossiya» [Multimedia Internet portal "UNION. Belarus-Russia]. Access mode: https://rg.ru/2019/06/22/75-let-nazad-nachalasoperaciia-po-osvobozhdeniiu-belarusi-ot-fashistov.html (Accessed 10.03.2020).

2. Dokumenty po arkhitekture Belarusi izlichnykh fondov deyatelei kul'tury. Fond arkhiva M.S. Katsera. $1948 \mathrm{~g}$. [Documents on the architecture of Belarus from the personal funds of cultural figures. The archive fund of M.S. Katsera. 1948]. Institut iskusstvovedeniya, etnografii i fol'klora im. K. Krapivy NAN Belarusi. [Institute of Art History, Ethnography and Folklore. K. Krapiva of the National Academy of Sciences of Belarus]. Access mode: https://archives.gov.by/index. php?id=707874 (Accessed 15.03.2020).

3. Zbor pomnikay̆ gistryi i kul'tury Belarusi. U 7 tamakh [Collection of monuments of history and culture of Belarus. In 7 volumes]. Minsk, 1984-1988.

4. Gorbachev N. Nikolaevskii garnizonnyi sobor v Brestskoi kreposti [Nikolaev garrison cathedral in the Brest Fortress]. Mir Bozhii, 2012. No. 18, pp. 87-89.

5. Povnyi F. Khramovoe sooruzhenie kak propoved', a khramovoe prostranstvo traditsionno [The temple structure as a sermon, and the temple space is traditional]. Literaturnaya gazeta, 2020, no. 4 (6722).

6. [Tsikl publikatsii materialov iz Natsional'nogo arkhiva Respubliki Belarus' k 70-letiyu Velikoi Pobedy] [Series of publications of materials from the National Archives of the Republic of Belarus to the 70th anniversary of the Great Victory]. Belarus' segodnya [Belarus Today]. Access mode: https://www.sb.by/articles/do-polnoy-pobedy-eshche-trimesyatsa.html (Accessed 20.02.2020).

Слюнькова Инесса Николаевна (Москва). Доктор архитектуры, член-корреспондент РААСН. Главный научный сотрудник НИИ теории и истории изобразительных искусства Российской академии художеств (119034, Москва, ул. Пречистенка, д. 21. НИИ PAX). Эл. почта: inessa_s@yahoo.com.

Slyunkova Inessa N. (Moscow). Doctor of Architecture, Corresponding Member of RAACS. Chief Researcher at the Research Institute of Theory and History of Fine Arts of the Russian Academy of Arts (21 Prechistenka str. 119034 Moscow, 119034. NII RAH).E-mail: inessa_s@yahoo.com. 